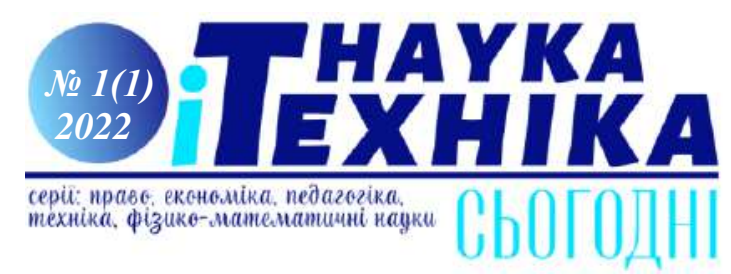

УДК 37.018 .43

https://doi.org/10.52058/2786-6025-2022-1(1)-49-57

Кульчицький Віталій Йосипович доктор педагогічних наук, доцент, професор кафедри педагогіки вищої школи та суспільних дисциплін, Тернопільський національний медичний університет імені І. Я. Горбачевського МО3 України, вул. майдан Волі, 1, м. Тернопіль, 46001, тел.: (0352) 52-44-92, https://orcid.org/ 0000-0001-5863-3204

\title{
СУТНІСНІ ХАРАКТЕРИСТИКИ ДИСТАНЦІЙНОГО НАВЧАННЯ В СИСТЕМІ ВИЩОЇ ШКОЛИ
}

Анотація. У статті розкрито сутнісні характеристики дистанційного навчання. Актуальність дослідження визначається тим, що дистанційне навчання $є$ одним із перспективних напрямів розвитку системи вищої освіти. 3'ясовано, що перед вищою освітою відкриваються нові горизонти, пов'язані 3 інноваційними освітніми технологіями, які сприяють створенню знань, управлінню ними, їх поширенню, доступу до них i контролю за якістю засвоєння та застосування на практиці. Таким чином, зростання технологічності, модерні освітні тенденції є детермінувальними чинниками, які організовують дистанційне навчання як ефективний механізм засвоєння студентами змісту освітніх програм. Констатовано, що наслідком процесу інформатизації суспільства та освіти є поява дистанційного навчання як найбільш перспективної, гуманістичної, інтегральної форми освіти, орієнтованої на індивідуалізацію навчання. Зосереджена увага на тому, що дистанційну освіту розуміють, по-перше, як комплекс послуг, якими може скористатися будь-яка молода людина; по-друге, як технічну освітню систему, що підкреслюється поняттям інформаційно-освітнього середовища, i трактується як сукупність інформаційних ресурсів, технічних засобів і каналів телекомунікації. Зазначено, що дистанційна форма навчання передбачає створення і використання єдиного інформаційно-освітнього середовища, яке містить різні електронні джерела інформації, а саме: курси дистанційного навчання, електронні підручники, розташовані на вітчизняних освітніх серверах (для різних моделей дистанційного навчання): віртуальні бібліотеки; бази даних освітніх ресурсів; веб-квести, призначені для цілей навчання; телекомунікаційні проєкти; віртуальні методичні об'єднання викладачів; телеконференції, форуми для викладачів та студентів; консультаційні віртуальні центри; наукові об'єднання студентів.

Ключові слова: дистанційне навчання, інформаційні технології, вища школа, викладач, студент. 


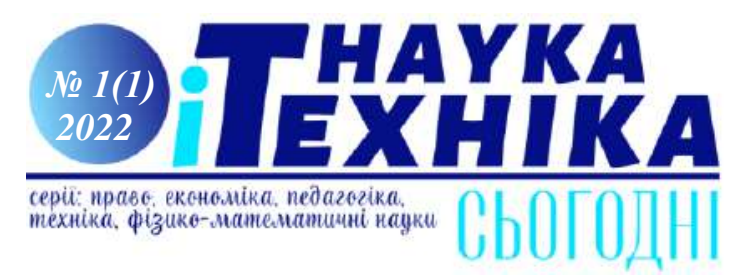

Незначний за обсягом час існування системи дистанційної освіти, що базується на використанні сучасних технічних засобів збереження та доставки інформації, масової комунікації, не сприяє створенню розвинених наукових теорій у цій галузі. У тому вигляді, в якому вони вже існують, вони більше стосуються технічної й організаційної сторін функціонування цієї системи. Суто психологічні і педагогічні аспекти системи дистанційної освіти до сьогодні залишаються найменш науково-теоретично обгрунтованими й усвідомленими. Однак вітчизняний і зарубіжний досвід практики дистанційної освіти, що вже склався, наближає нас до розуміння сутності та особливостей цієї системи, заснованої на використанні специфічних освітніх технологій, сучасних методик навчання, технічних засобів і способів передачі інформації, інформаційних та телекомунікаційних технологій, дає змогу осмислити їх на рівні теоретичної концепції. Базовим для створення будь-якої концепції $\epsilon$ визначення основних їі понять.

Дистанційна освіта характеризується також як якісно новий, прогресивний вид навчання, що виник в останній третині $\mathrm{XX}$ ст. завдяки новим технологічним можливостям, які з'явилися внаслідок інформаційної революції, і на підставі ідеї відкритої освіти [1, С. 10]. В основу цього виду навчання покладено самостійну інтерактивну роботу студента зі спеціально розробленими навчальними матеріалами.

Аналіз останніх досліджень і публікацій. Проблемам з питань розвитку дистанційної освіти присвячені роботи багатьох зарубіжних науковців, таких як: Р. Деллінг, Г. Рамблє, Д. Кіган, М. Сімонсон, М. Мур, А. Кларк, М. Томпсон ін. та відповідно вітчизняними, такими як: О. Андрєєв, Г. Козлакова, I. Козубовська, А. Мінаков,В. Олійник, С. Полат, А. Хуторський.

Питаннями впровадження і використання інформаційно-комунікаційних технологій у вищій школі займаються: А. Андрєєв, Т. Вахрущева, М. Загірняк, В. Кухаренко, С. Полат, А. Хуторський, І. Козубовська, О. Рибалко, Є. Долинський, М. Бухаркіна, Я. Ваграменко, В. Вержбіцький, К. Верішко, В. Каймін, В. Солдаткін, Н. Сиротенко, Н. Корсунська, О. Скубашевська, В. Осадчий та ін.

Аналіз і узагальнення досвіду дистанційної освіти, проведений В. Кухаренко, О. Рибалко, Н. Сиротенко, В. Овсянніковим дає змогу виокремити низку властивостей, що розкривають їі сутність.

Серед багатьох публікацій щодо використання методів змішаного навчання, можна виокремити наукові праці та педагогічні блоги таких авторів як: В. Кухаренко, К. Бугайчук, С. Локтєва, О. Мокін, С. Тіхомірова та ін.

Мета статті - розкрити особливості дистанційного навчання в системі вищої школи, а також його сутнісні характеристики.

Виклад основного матеріалу. Наслідком суспільства та освіти $є$ поява дистанційного навчання як найбільш 
перспективної, гуманістичної, інтегральної форми освіти, орієнтованої на індивідуалізацію навчання.

Передумовами розвитку дистанційного навчання є:

- бурхливий розвиток інформаційних технологій;

- неперервне зниження вартості послуг на підключення та використання глобальної мережі Інтернет, iї ресурсів і сервісів;

- суттєве поглиблення процесів упровадження інформаційних технологій в освітню практику;

- значне поширення засобів комп’ютерної техніки серед населення.

Аналіз та узагальнення літературних джерел свідчать, що сьогодні $є$ різні трактування сутності дистанційної освіти, які відображають різноманіття підходів до його тлумачення. У багатьох випадках термін «дистанційна освіта» використовується поряд або замість терміна «дистанційне навчання», «дистантне навчання» тощо. Можна навести велику кількість визначень поняття дистанційне навчання, що відображає різноманітні підходи до його розуміння. Ось деякі з них.

1. Дистанційне навчання є формою освіти, поряд з очною та заочною, за якою в освітньому процесі використовуються кращі традиційні та інноваційні засоби i форми навчання, що грунтуються на комп'ютерних i телекомунікаційних технологіях.

Основою освітнього процесу в дистанційному навчанні є цілеспрямована й контрольована інтенсивна самостійна робота студента, котрий може навчатися в зручному для себе місці, за індивідуальним розкладом, маючи комплект спеціальних засобів навчання й погоджену можливість контакту з викладачем по телефону, електронною та звичайною поштою, а також очно.

2. Дистанційне навчання $є$ цілеспрямованим інтерактивним асинхронним процесом взаємодії суб'єктів і об’єктів навчання між собою та із засобами навчання, причому процес навчання індиферентний до їхнього просторового розташування. Освітній процес проходить у специфічній педагогічній системі. Елементами цієї системи є підсистеми: мета навчання; зміст навчання; засоби навчання; організаційні форми навчання - ідентифікаційно-контрольна, навчально-матеріальна, фінансово-економічна, нормативно-правова, маркетингова [2].

3. Дистанційна освіта - особлива, досконала форма, яка поєднує елементи очного, очно-заочного, заочного й вечірнього навчання на основі нових інформаційних технологій та систем мультимедіа. Сучасні засоби телекомунікацій та електронних видань дають змогу подолати недоліки традиційних форм навчання, зберігаючи при цьому всі їхні позитивні риси.

4. Дистанційна освіта - комплекс освітніх послуг, що надаються широким колам населення в країні й за кордоном за допомогою спеціалізованого інформаційного освітнього середовища, що базується на засобах обміну 


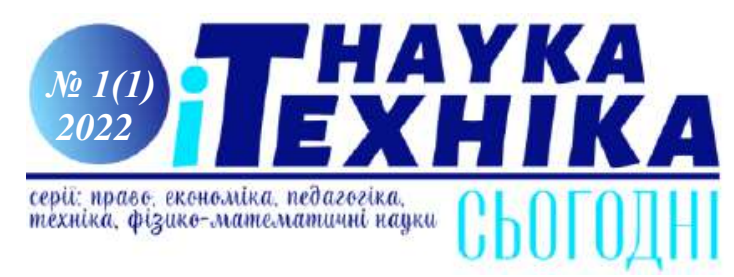

навчальною інформацією на відстані (супутникове телебачення, радіо, комп'ютерний зв'язок та інше). Інформаційно-освітне середовище дистанційного навчання становить системну сукупність, що організувалася із засобів передачі даних, інформаційних ресурсів, протоколів взаємодії, апаратно-програмного та організаційно-методичного забезпечення, яке орієнтується на задоволення освітніх потреб користувачів. Дистанційне навчання є однією з форм неперервної освіти, що покликана реалізувати права людини на освіту й отримання інформації.

5. Дистанційне навчання - нова організація освітнього процесу, що базується на принципі самостійного навчання студента. Середовище навчання характеризується тим, що студенти в основному, а часто й повністю, віддалені від викладача у просторі й часі, водночас вони мають можливість у будь-який момент підтримувати діалог за допомогою засобів телекомунікації.

6. Дистанційне навчання - сукупність інформаційних технологій, що забезпечують доставку студенту основного обсягу навчального матеріалу; інтерактивну взаємодію студентів та викладачів у процесі навчання; надання студентам можливості самостійної роботи із засвоєння навчального матеріалу; а також оцінювання їхніх знань та умінь у процесі навчання.

7. Дистанційне навчання - це нова сходинка заочного навчання, на якому забезпечується застосування інформаційних технологій, що грунтуються на використанні персональних комп'ютерів, відео- та аудіотехніки, космічної техніки й оптичних систем зв'язку [2].

8. Дистанційне навчання - це універсальна гуманістична форма навчання, що базується на використанні широкого спектра традиційних i нових інформаційних та телекомунікаційних технологій, технічних засобів, які створюють умови для вибору студентами вільних освітніх дисциплін, які відповідають стандартам, діалоговому обміну з викладачем; при цьому процес навчання не залежить від розташування студента в просторі та часі.

9. Дистанційне навчання - це, за словами Л. Хуторського, електронний варіант очного або заочного навчання, що адаптує традиційні форми занять та паперові засоби навчання в телекомунікаційні. Дистанційне навчання покликане вирішувати специфічні завдання стосовно розвитку творчої складової освіти й проблеми, складні для розв'язання у звичайному навчанні, зокрема:

- підсилення активної ролі студента у власній освіті: у постановці освітньої мети, виборі домінантних напрямків, форм і темпів навчання в різноманітних освітніх царинах;

- різке збільшення обсягу доступних освітніх масивів, культурноісторичних досягнень людства, доступ до світових культурних та наукових скарбів для студентів з будь-якого населеного пункту, де є телезв'язок;

- отримання можливості спілкування студента 3 викладачемпрофесіоналами, 3 ровесниками-однодумцями, консультування у фахівців високого рівня незалежно від їхньої територіальної розташованості; 
- збільшення евристичної складової навчального процесу за рахунок застосування інтерактивних форм занять, мультимедійних навчальних програм;

- більш комфортні, порівняно 3 традиційними, умови для творчого самовираження студента, можливість демонстрації продуктів своєї творчої діяльності для всіх, широкі експертні можливості оцінювання творчих досягнень;

- можливість змагання з великою кількістю ровесників, що знаходяться у різних містах та країнах, за допомогою участі у дистанційних проєктах, конкурсах, олімпіадах [2].

Отже, наведені визначення доводять, що дистанційну освіту розуміють, по-перше, як комплекс послуг, якими може скористатися будь-яка молода людина; по-друге, як технічну освітню систему, що підкреслюється поняттям інформаційно-освітнього середовища, i трактується як сукупність інформаційних ресурсів, технічних засобів і каналів телекомунікації.

Серед тлумачень змісту дистанційного навчання виділяють два підходи, які істотно розрізняються з дидактичної точки зору.

Перший досить розповсюджений сьогодні підхід такий: дистанційне навчання - обмін інформацією між студентом і викладачем (групою студентів) за допомогою електронних мереж чи інших засобів телекомунікацій. Студент розглядається як одержувач деякого інформаційного змісту і системи завдань для його засвоєння. Результати самостійної роботи повертаються знову викладачу, який оцінює якість і рівень засвоєння матеріалу. Під знаннями розуміється трансльована інформація, а особистий досвід студентів i діяльність щодо конструювання знань майже не організовуються.

Другий підхід принципово відрізняється від попереднього. Основою дистанційного навчання виступає особистісна продуктивна діяльність студентів, яка будується за допомогою сучасних засобів телекомунікацій. Цей підхід припускає інтеграцію інформаційних і педагогічних технологій, що забезпечують інтерактивність взаємодії суб'єктів освіти і продуктивність навчального процесу. Обмін і пересилання інформації відіграють у цьому випадку роль допоміжного середовища організації продуктивної освітньої діяльності студентів. Навчання відбувається в реальному часі (чат, відео зв'язок, спільні для віддалених студентів і викладача «віртуальні дошки» із графікою тощо), а також асинхронно (телеконференції на основі електронної пошти, форуми). Паралельно зі створенням студентами освітніх продуктів відбувається їх внутрішнє освітнє зростання. Особистісний, креативний i телекомунікативний характер освіти - основні риси дистанційного навчання цього типу. У процесі дистанційного навчання передбачається наявність викладача i студентів, їх спілкування, спілкування між собою, а також наявність у системі підручника, необхідного комплекту засобів навчання.

Розвиток системи дистанційного навчання обумовлений сукупністю переваг i можливостей. Це насамперед більш гнучкі умови навчання для 


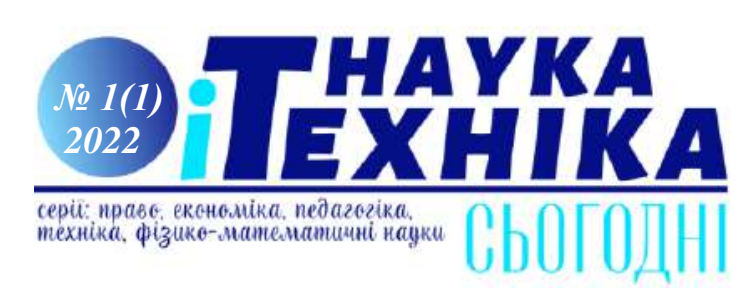

молодих людей, які не змогли чи не можуть здобути освіту традиційним шляхом через віддаленість від кваліфікованих навчальних закладів, фізичних недоліків, індивідуальних особливостей і потреб [3, С. 318-323].

Дистанційне навчання спроможне задовольнити додаткові освітні потреби студентів, особливо 3 навчальних дисциплін, змістовна частина яких дуже швидко змінюється. Талановитий студент може, наприклад, одночасно навчатися дистанційно у висококваліфікованих фахівців, які знаходяться в будь-якому куточку країни і світу, не залишаючи свого місця проживання. За допомогою електронних мереж студент з будь-якого міста чи села має доступ до світових культурних $\mathrm{i}$ наукових скарбів, навчається в престижних університетах світу.

Дистанційне навчання має такі переваги перед очним

- оперативні (подолання бар'єрів у просторі та часі, одержання актуальної «свіжої» інформації, швидкий зворотний зв’язок);

- інформаційні (зростає доступність освітньої інформації, що знаходиться на спеціалізованих серверах, постачається студентові за допомогою інтерактивних веб-каналів, публікується в телеконференціях, списках розсилання й інших засобах мережі Інтернет);

- комунікаційні (збільшується кількість потенційних учасників навчання студентів, викладачів, фахівців, які оперативно взаємодіють один з одним за допомогою електронних мереж, ліквідуються територіальні обмеження для проведення Інтернет-занять, проєктів, олімпіад);

- педагогічні (внаслідок специфіки дистанційних телекомунікацій навчання стає більш мотивованим, інтерактивним, технологічним індивідуалізованим, спрощується публікація студентських наукових робіт у мережі, їх експертиза та оцінка);

- психологічні (створення більш комфортних, порівняно з традиційними, емоційно-психологічних умов для самовираження студента, зняття психологічних бар'єрів і проблем, усунення помилок усного спілкування);

- економічні (загальні витрати на навчання зменшуються через економію транспортних витрат, витрат на оренду приміщень, скорочення «паперового» діловодства і тиражування посібників);

- ергономічні (студенти і викладачі мають можливість розподіляти час занять за зручним для себе графіком і темпом, вибирати і використовувати для занять найбільш придатну техніку і комп'ютерне устаткування) [4, С. 49-53].

Дистанційна форма навчання передбачає створення i використання єдиного інформаційно-освітнього середовища, яке містить різні електронні джерела інформації, а саме:

- курси дистанційного навчання, електронні підручники, розташовані на вітчизняних освітніх серверах (для різних моделей дистанційного навчання):

- віртуальні бібліотеки;

- бази даних освітніх ресурсів; 
- веб-квести, призначені для цілей навчання;

- телекомунікаційні проєкти;

- віртуальні методичні об'єднання викладачів;

- телеконференції, форуми для викладачів та студентів;

- консультаційні віртуальні центри;

- наукові об’єднання студентів.

Навчальне середовище формується таким чином, щоб студент мав вільний доступ з будь-якого курсу до:

- інформаційного забезпечення (довідники 3 відповідних предметів, енциклопедії, консультаційний центр);

- необхідних розділів курсів із суміжних галузей знань;

- лабораторних робіт, практикумів;

- веб-квестів;

- проєктів.

Разом 3 тим, науковець А. Мінаков, аналізуючи соціально-психологічні аспекти дистанційної освіти, підкреслює, що сьогодні стрімке поширення сучасних комп’ютерних засобів телекомунікації ставить на порядок денний цілу низку філософських, політичних і соціальних питань, пов'язаних з цим явищем. Особливе місце займають психологічні феномени впливу нового інформаційного середовища як на особистість людини, так і на всю систему його відносин зі світом. Вчений зазначає, що на сучасному етапі Інтернет перестає бути просто системою збереження й передачі надвеликих обсягів інформації і стає новим психологічним середовищем та сферою життєдіяльності людини. У користувачів комп'ютерних мереж виникає низка психологічних новотворів (інтересів, мотивів, потреб, установок, форм психологічної і соціальної активності), безпосередньо пов'язаних із цим новим простором [5, С. 202-207].

Висновки. Молода людина, стаючи особистістю, не тільки накопичує, але й трансформує ті або інші соціальні факти, для чого очевидна потреба в наявності у неї певних якостей, навичок. Вона повинна не тільки усвідомлювати необхідність у такій діяльності, але й бути здатною здійснювати iii, а отже, бути не тільки залученою в культурну підсистему даного співтовариства, але й мати певний рівень знань, творчого мислення, інтелігентності і т.д. Тобто, для перетворення людині необхідний інструмент. Таким інструментом у даному випадку виступає дистанційна освіта.

Отже, основною ідеєю дистанційного навчання є створення навчального інформаційного середовища, що охоплює комп'ютерні інформаційні джерела, електронні бібліотеки, відео- та аудіотеки, книги i навчальні посібники. Складниками такого навчального середовища є як студенти, так і викладачі, взаємодія яких здійснюється за допомогою сучасних телекомунікаційних засобів. Таке навчальне середовище дає унікальні можливості студентам для одержання знань як самостійно, так і під керівництвом викладачів. 
